\title{
An Introduction to the World of Monoranjan Byapari \\ With a translated excerpt from Itibritte Chandal Jiban (Prathama Khanda)
}

\section{Sayantan Mondal}

\begin{abstract}
:
Can an introduction to a text become an appeal, a warning or perhaps a statement on its own? Can it become a site of foregrounding certain uncertainties which the text stands for? This is an attempt of such an introduction to a world of words and actions, to a life which can hardly find a parallel. The paper proposes to do so by taking out three aspects of Monoranjan Byapari's writing. First, it attempts to delve into the recent debate about the primacy of identity politics and by not trying to be judgemental about this seemingly never-ending debate, this paper will try to reflect upon it from the perspective of the novelist Monoranjan Byapari's world. Second, this paper will focus on the complexity of identity itself by taking registered clues in the writing of Byapari where instead of the restriction of a single tone what looms large is a spectrum of identity and a man's breaking into all of them equally. And third, this paper will be an attempt to dissuade attempts of easy linear meaning making by dissecting layers of linguistic complexity that crowds Byapari's world of letters and imagination.
\end{abstract}

An introduction may remain as a cluster formal words catered in the beginning of the process of knowing something or someone. But, it hardly remains so. Introduction has often crossed that boundary of formality and tended to be something more an appeal, a warning or perhaps a statement on its own. The act of introducing, thus, has always been tentatively definite in its nature. It has become a site of foregrounding certain uncertainties which the text or the object, which is being introduced, stands for. This is an attempt of such an introduction to a world of words and 
actions, to a life which can hardly find a parallel.

Monoranjan Byapari, a rickshaw puller, a coolie, a waiter, a helper and so many other things by occupation, has made a miracle one day by starting to write. It is a miracle, atleast, to our eyes which is accustomed to expect certain ways of writing when we read. It is a miracle to our eyes which is accustomed to expect a balance of suspense and relaxed space made of words when we read. It is a miracle to us who are accustomed to see a rickshaw puller pulling a rickshaw but not seeing him asking meaning of difficult words, writing stories, sitting in conferences and publishing. Indeed, it is needless to say, Monoranjan Byapari is a miracle man whose love for life has driven him from close encounters with death to a shabby corner of his shanty home where he wrestles with words, memories and writes life.

Itibritte Chandal Jiban or Chandal Life in Memoir, is a testament of a dalit life by Monoranjan Byapari. In his own words, it is a naked, unornamented truth of life which had supplied resources for his writings. Apprehending our customary apprehensions, Monoranjan Byapari has gone on length to explain why then another autobiography. No doubt, he has answered the questions to perfection. But, the fact that he himself raised the question before anyone of us asking, points to a few noteworthy aspects of his world, of his life. In this introduction, I will try to bring forward and focus on these aspects which the author's introduction plays with.

\section{Section I: A Dalit writer and his self :}

In recent times we have encountered a debate in different aspects of our social, political life. The debate is about the primacy of identity politics. While one side claims that identity centric politics divides, singles out people and distances them from all other primary political sloganing like class, the other side has clinged to it often recognising that as their last resort. This is not a platform to be judgemental about this debate, nor is this an attempt to solve this riddle which seems neverending. Rather, 
my attempt will be to read Monoranjan Byapari and about his self-identity, his 'me' which is at the centre of his autobiography Itibritte Chandal Jiban.

My first entry point into this complex calculation will be the equation between the self of the author and the question of self identity. Western theorisation has equipped our reading abilities to an extent that we are well aware of the author function and its limits. We know well the text and its seamless boundaries. And we know how to process 'doxa' (received knowledge) and go beyond it by contextualising it or by so many other means. However, in today's copyrighted world letters and sentences and their curious combinations are safeguarded to the extent that thought, meaning and words are hardly separable. And therefore, when a writer starts writing about the self, the readers though credit his attempt and recognise the stamp of his self identity do contextualise it with other similar attempts. This is where we have our first point of departure. If Monoranjan Byapari is to be contextualised what will be the context. The text at hand, Itibritte Chandal Jiban, has limited that scope for us. In fact, one of the greatest author of this generation, Maheswata Devi testifies this fact through her letter of introduction.

Author Monoranjan Byapari is known to me for years, whom I have seen growing up as an author. Author becomes through the process of writing. Monoranjan has established this saying in his life and works.... To be recognised in today's society whether one is by birth brahmin or chandal, that thinking, that mentality is no more. But, if someone is by birth a chandal, the path of his progress is not covered with flowers....it is difficult to build one's own identity in society only on the basis of his abilities. Who has no identity by birth or through family, for him it is more difficult to build an identity, recognition on the basis of his self-identity. Monoranjan Byapari wants to be recognised only through his self-identity. This is a welcome claim. My request, all of you read his autobiography and make others read.

- Introducing letter from Maheswata Devi published 
along with the autobiography.

It may be true that the process of writing, editing, revising makes a writer and Monoranjan Byapari is the product of similar hard work; it may be true that his yearnings to be known for his literary work, for his 'me' will find reflection in countless authors, poets, artists, but it is only a conditional truth. And the conditions separate his claims from thousand other writers and bring him closer to them who has similar life, the lives of dalits. Monoranjan Byapari and his 'me' is the representative of that mute section of the society who were never heard of, never expected to become vocal or write.

\section{Section II: The Fractured self and the imprints of dalit life:}

From 1981 to 2012, as a matter of time it is thirty-thirty two years. If I am asked - what have I written by wrestling with pen and paper all these years! Story? Novel? My answer will be - "none of that, I have written life." Only one life; its moving on, receeding, loosing, making others loose, getting lost, finding, getting bloody wounds and injuries, falling flat in the ground and struggling to stand up relying on the same ground, an intense yearning to touch the sky, etc. Therefore, it will not be illogical to say - my whole life is scattered in each of my story....That rickshaw puller named Naba, that truck helper named Lathkhor, that angry chandal named Jiban, that drunkard named Gurjal, that thief named Bhagaban, that coolie named Sripada, that dacoit named Aguntuk, that writer named Bangal - that's all me. All these are my fractured being.

- Monoranjan Byapari, Two Words from the Author, Itibritte chandal jiban.

Following our point of departure, recognising that the voice of Monoranjan Byapari is perhaps the voice of mute millions, one encounters the fractured self of the author in the beginning of this autobiography. The subjective position of the author is neither limited to nor in any way restricted by his professional 
identity. Rather, Monoranjan Byapari looms large in a spectrum of identity. Interestingly, the spectrum is constituted of the lowest strata of our society which is composed of rickshaw pullers, thieves, waiters, helpers, coolies, of people who dwell far below the poverty line. The self, thus, is not only torn among occupational identities, but among identities that moor one in specific caste and class categories simultaneously. And this provides the author the license to dictate terms, atleast in his writings, over a number of conflicting ideas - caste, class, regionality, nationality and so on. Monoranjan Byapari moves through the complex web of identities smoothly and with ease and mocks at the battle of theories as he asserts that the battle is after all for the class called have-nots which is invariably located at the cross section of all sorts of identities, groups. Itibritte Chandal Jiban, thus perhaps, earns the rights to have a laugh about the falling apart of the centre which could not hold the author's queries in a predetermined, specific category or zone; and, the fractured self by the strength of its fractured nature thus redefines what has been so long comfortably labelled as dalit and widens the path for future debates.

\section{Section III: Of Language, Humbleness and of Writing:}

As no ornament can be prepared without mixing impurity to the gold, likewise to steer stories, novels towards a fulfilment of some metaphors, alamkaras, similes, examples are sought to construct its body and its make up. Some additions and some deletions to the main event are also required. Past is passed as present and present is pushed towards future. Space, time and characters are altered. A lot of artistry is to be done. In an idol made out of all these tricks, the artist's artistry becomes the main factor. And the real material gets covered in these artistry - the husk-soil-wood or that 'truth'....Once a lengthy writing, titled "Saman Sakashe Tindin" was published on three horrific incidents of my life. A lot of readers read that with the pleasure of reading detective stories, praised the writer's skill. But no one could accept it as truth. Because that was a story. Whatever, stories are never true. To present that truth - that hard, rough, merciless, horrible 
reality in a trimmed, unornamented body, to present myself in the time-society-peoples' court for justice, this self-organic writing is created.

- Monoranjan Byapari, Two Words from the Author, Itibritte chandal jiban.

It would a sweeping statement to call Monoranjan Byapari's language difficult. A language that has a history of atleast two hundred years of modern grammatical development and evolution where it went through the creation and later merging of separate writing and speaking language, has been put to contain the life of a fractured self in this autobiography. And, the author who has never crossed the threshold of a school but learnt the language and its nuances from his daily life in station, in hotels, in prison when writes the language, it becomes more enriched with a curious mix of a colloquial and formal tones and vocabularies. Monoranjan Byapari has weaved a complex web of language with unforeseen use of punctuation to remain true to his emotions and challenges every reader who translates his writing for his or her own understanding. However, when this language is translated can it retain the local flavor of everyday life, can it strike the reader for its staggering movement, can it remind the reader of the self of the author at every period (.) - these questions are yet to be answered. And I hope the answer which we are going receive in future comes in affirmative so that Monoranjan Byapari does not lose his self in translation.

Before putting an end to this short introduction to the world of Monoranjan Byapari, let me focus on two very significant aspects which will perhaps help us to closely associate with this autobiographical writing; one, the art of writing and two, humbleness. Itibritte Chandal Jiban, atleast some parts of it will remind any careful reader of Sharan Kumar Limbale's Towards An Aesthetics of Dalit Literature. Not only the parts in which the author explicitly talks about the art but also his craft carries strong reminder for us. No reader is left at ease through his writing. And, the writing bears numerous stamps of a life unknown in the world 
of letters. This takes us to the next aspect, the author's humble attitude. Monoranjan Byapari sounds overwhelmingly humble in his autobiography. To his readers he never issues authoritative claims but pleads and begs and speaks in a language replete with sadness, shame, pity that our social structure imposed on him. However, one can only wish that his humble tone take frequent turns to haunt the readers, even when he acknowledges his inspirations humbly:

A lot of people helped me in lot of ways to reach here. They are so many in number that counts cannot count that.... am grateful to that back tearing stick which steered me towards future like a cow. Grateful to that light post too, to which I was tied. That helped me understand how sinful it is to be poor. I convey my gratitude that netted black van which sent me to the best university of the world - the prison. And I am most grateful to that rickshaw whose tyres one day became my fortune-wheel.

- Monoranjan Byapari, Two Words from the Author, Itibritte chandal jiban.

\section{Section IV: Translation from Bengali to English}

\section{Chandal Life In Memoir}

\section{(Itibritte Chandal Jiban)}

(Paragraph divisions and quotations have been done in accordance with the source text)

This is me. I know that I am not completely unknown to you. You have seen me so many hundred times in so many ways. Even then if you deny to recognise me, if I elaborate it to make you understand, then it will not seem so anymore. When the dark of the all unknowns will be removed you will think, yes I know him, I have seen this person.

Human memory is very weak. So to remind you of the old I will not insist on putting pressure on your memory. Just take a 
look at the green ground infront of your window. You will see a bare bodied rakhal' boy behind goats and cows running with a stick in his hand. You have seen this boy for years. The face, that's why, almost known to you. That is me. That is my boyhood.

Now come little out of your house. Where the alley of your's merge with the big road ${ }^{2}$, take a look at the junction teastall. Rough hair, smelly, torn genji $i^{3}$ worn, beaten at the hands of the owner, the boy that cries and washes the glasses - that is my adolescence.

Youth follows. Carrying mote $e^{4}$ in rail stations, balancing a load of bricks on the head and climbing bamboo bhaaras ${ }^{5}$ to second or third floor roof, driving rickshaws, watchmaking at night, helpering ${ }^{6}$ in long distance trucks, methor, dom ${ }^{7}$ - this way my youth had passed. In one or the other stage of this, in the roads, ghats, fields in some occassions or other you have definitely seen me. One cannot say, perhaps you have seen me in that decade of seventies ${ }^{8}$, running in the para ${ }^{9}$ alleys with bombs and pipeguns. Or police beating handcuffed me and picking up in a van.

Life kept mustard under my feet ${ }^{10}$. That's why nowhere, in no role I could stay for two days. I have slipped again and again. I am making audible that lagging behind, retreating lifestory. In my whole life, life has made me do so many things, even if I want, can I write all of them? This is a big disadvantage of autobiographythere is no cover. That cover is available in Novels. So there is no problem in disclosing a lot of things frankly.

Another problem of writing autobiography is, one has to beat one's own drum. Every human is beautiful in his own eyes. Their work is praiseworthy for them. That's why I am afraid, the toneless, rhythmless beating of my torn and tattered drum will irritate you. Because the picture of the society I am going to draw, is the same society, same time that you belong to. Who knows my complaining finger may also be raised in your direction!

I am not sure, someone has called life a theatre. From 
birth you proceed to death by each step - wounded and damaged with injuries and failures - sprinkling blood on turns of the road, searching the touch of immortality which glorifies life, makes it great, gives it immortality.

Not all can get that ambrosia. Few get that. The one gets it, his/her birth is a success, death is a success, life is a success. If you do not think I am arrogantly proud then let me tell you humbly that I have been touched by that ambrosia. Therefore, it will not be an audacity perhaps to utter that even if my life cannot be called a success it cannot be called a failure. Of course, I have no clear idea about what is truly success and failure.

I am born in an untouchable dalit family notified as criminal by birth. Whose life begins with grazing goats and is driven by the search of two morsels for the two ends of the day to so many types of "lewd, dirty abominable occupations." Though no opportunity to go to school came across but going to jail happened a few times. That man whom people wanted to kill quite a few times considering a nuisance on the earth, today when he is made to sit on a platform and garlanded, he is entitled to think that life has not deprived him completely.

Never crossed the threshold of a school; used to drive rickshaw in front of Jadavpur University; when his life and literary achievements are discussed in the journal of comparative Literature of the same university- vol. no. 46/2008-2009, covering twelve pages from page 125 to page 137 , he must be feeling gratified. When so many famous, respected people write about him with their powerful pens; Jugantar, Bartamaan, Anadabazar, Pratidin, Aajkaal'1" E.P.W, Kathadesh, Notun Khobor, Dinkaal, The Hindu, Statesman, Times of India, Dainik Jagoran, Hindustan Times - in such main stream newspapers and magazine his nameidenity gets published; when in popular television programme like 'Khaskhobor', 'Sadharon Asadharon' and 'Khonj Khobor' in Akash Bangla, in Tarar Khobor in Tara news, in 24 Ghanta, ETV news programmes feature him, he is entitled to think - his life is successful. 
Once I was going to Hyderabad invited by respected Tutun di (Professor Tutun Mukherjee), Head of the Department of Comparative Literature, University of Hyderabad. From station I was going in an auto rickshaw. I told the driver to take me to the university guest house. The auto driver was knowledgeable. He keeps a tab of a lot of news of near and far. Knowing that I came from Kolkata, he asked - whether I know the rickshaw puller of Kolkata, who has never been to a school and now an established author!

I told him - I know him. And it is not even slightly wrong that noone knows him like me. I know him much more than the Alka didi who wrote a novel about him. That makes me. My me.

In extinct East Pakistan, I was born in a poor dalit family of Turukkhali Village near Pirich Pur of district of Barishal. That was a Sunday in the month of scorching Baishakh.

On that night, there was a powerful kalboisakhi ${ }^{12}$ storm. The sheds of the huts of so many poors flew away in that storm. Thick branches from huge trees broke down. People were crying, lamenting, getting scared of the horrible sound of thunder. My mother saved me from that fiery rage of the angry nature with the cover of her bosom.

I have heard from my mother, that day we did not have a single grain of rice to cook in our house. My father who used to rear his family through contract-labour ${ }^{13}$ - who could supposedly toil like a buffalo, had no job on those days. As a consequence, firing the stove in the kitchen stopped since last three-four days. People around, who were of the same caste, relatives were all poor like us - they eat what they earn. In those households kindness was still not extinct. That's why some of them used to provide my mother with handful rice from their own share. In this way an unfortunate housewife somehow survived with the child in the womb.

That day in the morning my father was out on the road from home without even drinking water, if some rice can be managed 
from somewhere. In this area the most well to do people were Bhattacharya babus ${ }^{14}$. I have heard from my mother that after the harvest four heaps of paddy used to be thrashed in their granary. The heaps of paddy used to be so high that if women tried to look at the top of it, their veil would have dropped from their head. My father went to that house in the hope to borrow some rice.

They lend rice, cash money to the village people in difficult times. One has to repay that by working in the field during harvest season.

But now the time is different. Only four-five years back country has been partitoned. This is a time when people are leaving for India in groups. Some members of Bhatchaj ${ }^{15}$ family meanwhile had already left. The rest are also eager to go. But it is not an easy task to do a proper management of all that land before one leaves. If one lends now, none knows whether one will be ever able to collect it back. Therefore, in exchange of rice they thought it to be wise to make my father do some work right then and made him cut a mango tree into small wooden strips - which could be used for cooking.

This is like Munshi Premchand's another story in another context ${ }^{16}$. But unlike the main character of that story my father did not have to lose his life in hunger, thirst and labour. He managed to return home tying some rice in gamcha ${ }^{17}$ after finishing his work. After the end of the day when he reached back home it was already evening. And the hints of kalboisakhi has started galloping by darkening the whole sky. That will begin its tandava over the whole place in a few moments.

I am the first born of my parents. After me two more brothers and sisters were born. In those days it was the rule that the wife will give birth to the first child in her mother's house. Women used to be married of at a very young age. And lot of women used to die while giving birth at that tender age. And that's why the rule; lest they are accused that the people in the in law's place have not taken care of the mother. Unfortunately, my mother had 
no mother's house ${ }^{18}$. My grandmother was a child-widow. She married at the age of twelve and became a mother at the age of sixteen. After a few days my maternal grandfather passed away. Since there was no one else to take the responsibility of feeding and clothing my mother, she came back to her mother's house with a baby girl. Where already five of her widow sisters were staying. For this reason, in that locality that house was known in the name of "widow house". Of these six sisters there were only two children, my mother and her cousin brother.

My grandmother somehow managed living by keeping my mother in the safe custody of her aunts and by preparing puffed rice, muri $^{19}{ }^{19}$, sewing wraps and quilts and earning whatever little she could from the well to do houses of the village. When her girl was around eight or nine, my paternal grandfather was going in a boat through the river that flowed in front of the house. Suddenly his eye caught a small girl with flowing dark hair filling water in a small pot. He stopped the boat immediately and got down. Searched whose girl was that. And after that he finalised things talking with the guardians of the girl. And one day by paying twenty and one rupees as dowry he took her as daughterin-law to the famous "eight brothers' house" in Turukkhali village - to the Byapari house.

Our earlier surname was Mondal. It got shaded because of our grandfather. Once he fancied to take up business. Thinking so he took a boat load of beetle nut to Barishal city. However, the business was not bad. Consequently, while returning back from the city he purchased a ten rupee saree for his wife. The look of the saree bewildered all the villagers. One of them asked - "how much did you spend to buy the saree?" Grandfather became very cautious while disclosing the price. People say, "if he sells something - he would lose half. If he buys, he will lose it all." Remembering those words grandfather was hesitating to disclose the actual price. Who knows, perhaps he had been fooled this time as well. At last thinking a lot, he told - "the shop owner asked for eight rupees. After bargaining I got this in seven and half. That 
son of my brother-in-law ${ }^{20}$ not at all agreeing in anything less than that." Others said - "aren't you lying?" Grandfather answered with confidence, "what is there for me in lying! If I say I have brought that in 10 rupees, is there anyone who will believe?" At that moment a village person smiled and asked, "can you bring me one in the same price." "one! I can get ten", grandfather replied. As usual, when grandfather was getting on his boat at the time of his next visit to Barishal with beetle nuts, he found, someone is coming to him with seven rupees, someone with fifteen. Everyone wants one or two sarees. They were many in number.

Proverbs document that - bullet from the gun and words from the mouth, once they are out they cannot to be returned. Once grandfather has given his words, there was hardly anything for him to do. Therefore, after subsidising each purchase of saree with 2 and half rupees from his pocket, exhausting all his capital he came back from Barishal never to return again.

The story of grandfather's smartness did not remain a secret for long. One or two more Byaparis ${ }^{21}$ also visit the Barishal market. When they got to know of our grandfather's business deal they had a round of laughter and added the surname Byapari behind his name. For that reason I am not Monoranjan Mondal but Monoranjan Byapari. This is the real story behind becoming a Byapari.

In this country there may be many Monoranjan. Even one or two Byaparis can also found if searched. But no other Monoranjan Byapari is to be found. I am one and unique. I am the beginning and the end.

\section{NOTES}

1. Rakhal: Rakhal is the Bengali word denoting young boys who graze cows and goats.

2. Big road: This is a curious colloquial marker of road division in Bengali. Big road, in general, means main road which are used for buses, taxis and other transport. It is often interchangeably 
used with main road.

3. Genji: Meaning the underwear worn by men on the upperpart of their body, it is loan word into Bengali language. It, however, maintains an etymological connection to the island of Genji

4. Mote: Mote stands for the load that are carried over head by the coolies, porters and mootes (another bengali term for coolie). Mote is unique in its sense as it technically reduces stuff to be carried to a total dead weight. And perhaps on that ground distinguishes itself from load.

5. Bhaara: A huge makeshift ladder made of bamboo. It differs from common place ladder in terms of the distance between two consecutive steps which is roughly around 4 feet. It is used mostly by the masons for construction works.

6. Helpering: Derived from helper, i.e. the person who helps, this word helpering is commonly used in Hindi and bangla. It means the job of assistant in trucks. However, it has a number of other usages in other places and broadly stands for the profession of helping in such unorganised and casual sector.

7. Methor and Dom: Both these are known to be caste marker or names attached to the low caste people involved in the profession of scavenging and burning funeral pyres respectively.

8. Decade of seventies: Refers to the period of Naxalbari Movement in Bengal and parts of Bihar.

9. Para: an intimate locality centering alleys, mostly one or two alleys. It is a small stretch of place where people identify each other as a social unit and differentiates from others on the same basis. It has been a centre of flourishing sports club, religious, cultural activities where different paras engage each other in a friendly competition of glory and pomp.

10. Keeping Mustard under feet: It is a bengali proverb meaning 
restlessness.

11. These are bengali newspapers.

12. Kalboisakhi : It is the Bengali name for North Eastern storm which is frequent during summer in different parts of India.

13. Contract labour: This term is used to translate the Bengali Jan- Majoor. Jan or jana which means public also used to denote labour. It is interesting to note that this category of labour which emerged as a labour identity stands for all sorts of casual contract labour who can be found gathered at a particular place in cities and towns and ready for any kind of job offered in exchange of money.

14. Bhattacharya is a Bengali Hindu brahmin surname. It has often become a prestigious caste identity marker and been commonly used without the first name to denote a group of people or even a particular person.

15. A common colloquial and altered pronunciation of Bhattacharya.

16. Sadgati is a short story with remarkably similar storyline by Munshi Premchand which depicts the cruel death of a dalit villager as a result of inhuman exploitation of the caste system. Manoranjan Byapari makes a reference to this famous story which also had been cinematised in 1981 by Satyajit Ray.

17. Gamcha is a cotton made piece of cloth, approximately 6 feet in length and 2 feet in width. It is used like a towel for all the same purpose. However, gamcha has a history of nationalism linked to it and it has a well deserve place in everyday life as it serves innumerable purposes other than the obvious ones. For example, one can think of using it as a cushion under head as a replacement of pillow or over head for carrying bricks or any load.

18. Mother's house is not a very common usage in Bengali. 
Though the parents' house left by a woman due to marriage is often referred to as 'baper bari' (Pitri griha in sadhu language), i.e. father's house, rare occasional usage of mother's house or 'matri griha' points at an emphasis on this fact and simultaneously hints at interesting ritualistic practices like the mother going to mother's house during childbirth.

19. Muri, a Bengali word is a common staple food, made out of rice, in large parts of India known in different names like murmure in Telangana and Andhra region.

20. Saala literally meaning brother in law has long liberated itself from this relational usage only and became a part of slang. It would be wrong to translate saala as brother in law except in cases like this where it is used along with other markers of relational terms such as son, daughter, etc.

21. Byapari literally means businessman. Derived from vyapar or byapar which mean business.

\section{REFERENCES}

Byapari, Monoranjan. Itibritte Chandal Jiban ( $3^{\text {rd }}$ ed.). Kolkata Prakashan. Kolkata, 2014. 